\title{
Potassium availability in Brazilian semiarid soils cultivated with melon ${ }^{1}$
}

\author{
Kariolania Fortunato de Paiva ${ }^{2}$, Pedro Jorge da Silva Severo², \\ Flávio Sarmento de Oliveira ${ }^{3}$, Lauriane Almeida dos Anjos Soares ${ }^{2}$, Josinaldo Lopes Araujo ${ }^{2}$
}

\section{ABSTRACT}

Haplic Vertisols and Typic Quartzipsamments are among the main classes of soils used for melon production in the Brazilian semiarid region. Potassium $(\mathrm{K})$ is the nutrient most extracted by yellow melon fruits and, for this reason, high doses of potassium fertilizers are often applied to these soils. This study aimed to evaluate potassium fractions in soils of the Brazilian semiarid region, during the cultivation cycle of fertigated yellow melon. Two experiments were carried out with two types of soil (Haplic Vertisol and Typic Quartzipsamment). For the Vertisol, a 7 × 2 [seven evaluation periods and two soil layers $(0-20 \mathrm{~cm}$ and $20-40 \mathrm{~cm})]$ factorial arrangement was established, with four replications, totaling 56 experimental units. For the Quartzipsamment, a 9 × 2 [nine collection times and two soil layers $(0-20 \mathrm{~cm}$ and $20-40 \mathrm{~cm})]$ factorial arrangement was used, with four replications, totaling 72 experimental units. The nonexchangeable $\mathrm{K}$ fraction was dominant in both soils, mainly in the $0-20 \mathrm{~cm}$ layer, and represents an important reserve of this nutrient for melon cultivation, especially in Haplic Vertisols. The decrease in the concentrations of the soluble and exchangeable forms and the increase in the non-exchangeable form indicated an increase in the fixation of this nutrient, by fixation in the Vertisol and leaching in the Quartzipsamment, at the end of the melon cycle, when the amount of $\mathrm{K}$ accumulated by the plant was lower.

KEYWORDS: Cucumis melo, exchangeable potassium, potassium leaching.

\section{INTRODUCTION}

Melon (Cucumis melo) is a fruit species widely cultivated in several countries, due to its high economic value and excellent acceptance by international markets (Sun et al. 2017). In Brazil, the states of Rio Grande do Norte and Ceará are the largest national producers, accounting for about $72 \%$

\section{RESUMO}

Disponibilidade de potássio em solos da região semiárida do Brasil cultivados com melão

Vertissolos Háplicos e Neossolos Quartizarênicos estão entre as principais classes de solos utilizadas para a produção de melão, na região semiárida do Brasil. O potássio (K) é o nutriente mais extraído pelos frutos de melão amarelo; por isso, nesses solos, são frequentemente aplicadas altas doses de fertilizantes potássicos. Objetivou-se avaliar as frações de $\mathrm{K}$ em solos da região semiárida do Brasil, durante o ciclo de cultivo do melão amarelo fertirrigado. Dois experimentos foram conduzidos em duas classes de solo (Vertissolo Háplico e Neossolo Quartzarênico). Para o Vertissolo, os tratamentos compreenderam arranjo fatorial $7 \times 2$ [sete períodos de avaliação e duas camadas de solo $(0-20 \mathrm{~cm}$ e $20-40 \mathrm{~cm})]$, com quatro repetições, totalizando 56 unidades experimentais. Para o Neossolo, os tratamentos compreenderam arranjo fatorial $9 \times 2$ [nove épocas de coleta e duas camadas de solo (0-20 cm e 20-40 cm)], com quatro repetições, totalizando 72 unidades experimentais. A fração $\mathrm{K}$ não trocável foi dominante em ambos os solos, principalmente na camada de 0-20 cm, e representa importante reserva desse nutriente para o cultivo de melão, principalmente no Vertissolo. A diminuição nas concentrações das formas solúvel e trocável e o aumento da forma não trocável indicaram aumento na fixação desse nutriente, por fixação no Vertissolo e lixiviação no Neossolo, ao final do ciclo do melão, quando a quantidade de $\mathrm{K}$ acumulada pela planta foi menor.

PALAVRAS-CHAVE: Cucumis melo, potássio trocável, lixiviação de potássio.

of the entire Brazilian production (587,692 tons), in 2019 (IBGE 2019).

Potassium $(\mathrm{K})$ is the nutrient most extracted by this crop (Oliveira et al. 2016), and it is also the one that most influences the yield and quality of melon fruits (Silva et al. 2014), contributing to the improvement of fruit quality (Filgueira 2013, Silva et al. 2014). The physiological importance of this

${ }^{1}$ Received: May 29, 2020. Accepted: Aug. 17, 2020. Published: Oct. 07, 2020. DOI: 10.1590/1983-40632020v5063663.

${ }^{2}$ Universidade Federal de Campina Grande, Centro de Ciências e Tecnologia Agroalimentar, Pombal, PB, Brasil.

E-mail/ORCID: kariolaniafortunato@gmail.com/0000-0003-1636-7598,pjorgesevero33@gmail.com/0000-0001-6751-8902, laurispo.agronomia@gmail.com/0000-0002-7689-9628,jhosinal_araujo@yahoo.com.br/0000-0003-4669-6114.

${ }^{3}$ Universidade Federal do Rio Grande do Norte, Escola Agrícola de Macaíba, Macaíba, RN, Brasil.

E-mail/ORCID: sarmentodeoliveira@yahoo.com/0000-0002-1926-0991. 
nutrient is the consequence of its participation in the synthesis and translocation of sugars in the plant (Lester et al. 2010). Although there are no reports of $\mathrm{K}$ deficiency in the main Brazilian production areas, low contents of this nutrient lead to the production of hollow melons, with low sugar content and decreased market value (Pontes et al. 2010).

In the soil, $\mathrm{K}$ can be found in the following forms: structural, as part of primary minerals; not interchangeable, in which it is fixed between the layers of 2:1 type clay minerals; exchangeable, electrostatically adsorbed by negatively charged particles which normally control the $\mathrm{K}$ availability in the soil solution; and free in the soil solution (Kaseker 2016, Gurav et al. 2018). All of these forms, however, are in dynamic chemical equilibrium with the soil solution, but with different equilibrium constants, making it possible to release potassium reserves when the most readily available forms are removed from the soil solution (Mouhamad et al. 2016, NajafiGhiry et al. 2019).

Haplic Vertisols and Typic Quartzipsamment are important soil classes used for melon cultivation in the states of Rio Grande do Norte and Ceará, respectively (Oliveira et al. 2016). In these states, there is a lack of scientific data on the dynamics and efficiency of potassium fertilization in these soils, what has contributed to the use of equal doses of $\mathrm{K}$ for different soil classes. However, in the long run, this practice may lead to the unfeasibility of melon cultivation in the region, with a possible nutritional imbalance caused by the excess of K in the Vertisol, or by the loss of $\mathrm{K}$ through leaching in the Typic Quartzipsamment.

Despite the importance of the knowledge on the efficiency of $\mathrm{K}$ application for the melon crop grown in the Brazilian semiarid region, there are few studies aiming at improving the rates of nutrient consumption by the crop (Figueirêdo et al. 2017). Therefore, a deeper knowledge on the forms of $\mathrm{K}$ present in the soil of melon-producing regions could imply a more efficient use of $\mathrm{K}$, resulting in increased crop yield and reduced costs with fertilizers, in addition to avoiding future nutritional issues that might facilitate the appearance of pests and diseases (Mendes et al. 2016).

Thus, this study aimed to evaluate $\mathrm{K}$ fractions in two layers of two soil classes, in the Brazilian semiarid region, during the melon crop cycle.

\section{MATERIAL AND METHODS}

Two experiments were carried out in melonproducing areas located in a region of semiarid climate. The first experiment lasted from September to November 2014, in an area located at $5.0 \mathrm{~km}$ from the city of Governador Dix-Sept Rosado $\left(5^{\circ} 25^{\prime} 30^{\prime \prime} \mathrm{S}\right.$ and $37^{\circ} 31^{\prime} 50^{\prime}$ 'W), in the Açu-Apodi microregion of the Rio Grande do Norte state. According to the Köppen classification, the climate in the city is BSw', which corresponds to a very hot semiarid region, with mean annual rainfall of $406 \mathrm{~mm}$. The soil was classified as a Haplic Vertisol (Embrapa 2006). The second experiment was carried out from November 2015 to February 2016, in Aracati (4'51'3'S, 37 $27^{\circ} 15^{\prime}$ 'W and altitude of $46 \mathrm{~m}$ ), located in the microregion of the Aracati coast, Ceará state. According to the Köppen classification, the climate in Aracati is BSh, corresponding to a semiarid climate, with a dry summer season and mean annual rainfall of $985.76 \mathrm{~mm}$. The soil was classified as a Typic Quartzipsamment (Embrapa 2006). Climatic data were collected during the entire experimental period (Figure 1). The total accumulated rainfall was $12.2 \mathrm{~mm}$ in the Vertisol area and $3.1 \mathrm{~mm}$ in the Quartzipsamment area.
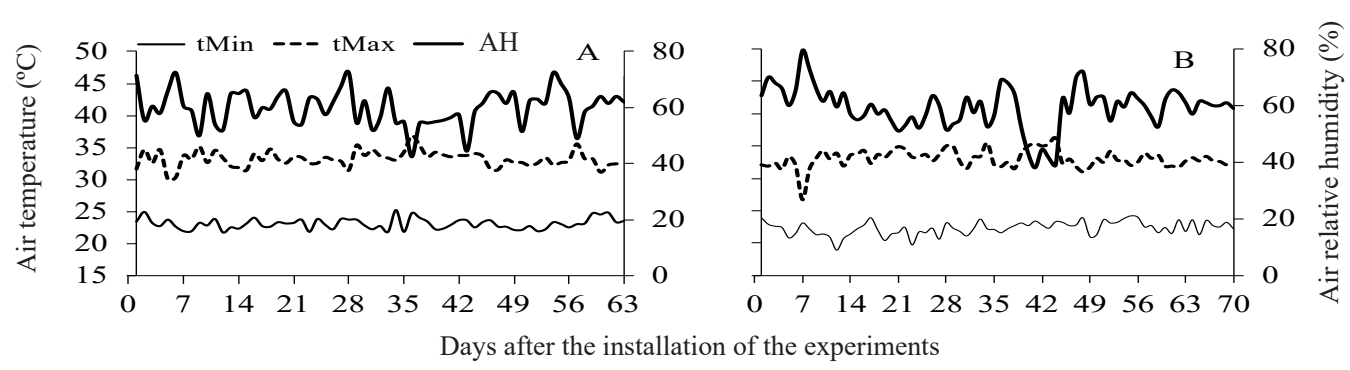

Figure 1. Values of minimum (tMin) and maximum (tMax) temperature and average humidity (AH) in the experimental areas of Haplic Vertisol (A) and Quartzipsamment (B) soils, during the experiments period. 
For both experiments, the soil samples were initially collected in the experimental areas at a depth of $0-20 \mathrm{~cm}$ and sent to the laboratory for their physical and chemical characterization (Embrapa 2011). The results of the soil analysis for the Haplic Vertisol were as it follows: $\mathrm{pH}\left(\mathrm{CaCl}_{2}\right)=7.5$; organic matter $=$ $14.6 \mathrm{~g} \mathrm{~kg}^{-1} ; \mathrm{P}=2.6 \mathrm{mg} \mathrm{dm}^{-3} ; \mathrm{Na}^{+}=0.40 \mathrm{cmol}_{\mathrm{c}} \mathrm{dm}^{-3}$; $\mathrm{K}^{+}=0.75 \mathrm{cmol}_{\mathrm{c}} \mathrm{dm}^{-3} ; \mathrm{Ca}^{2+}=17.30 \mathrm{cmol}_{\mathrm{c}} \mathrm{dm}^{-3}$; $\mathrm{Mg}^{2+}=4.8 \mathrm{cmol}_{\mathrm{c}} \mathrm{dm}^{-3} ; \mathrm{H}+\mathrm{Al}=1.0 \mathrm{cmol}_{\mathrm{c}} \mathrm{dm}^{-3} ; \mathrm{Al}^{3+}=$ $0.1 \mathrm{cmol}_{\mathrm{c}} \mathrm{dm}^{-3}$; sand $=311 \mathrm{~g} \mathrm{~kg}^{-1}$; silt $=447 \mathrm{~g} \mathrm{~kg}^{-1}$; and clay $=242 \mathrm{~g} \mathrm{~kg}^{-1}$. For the Typic Quartzipsamment, the results were: $\mathrm{pH}\left(\mathrm{CaCl}_{2}\right)=5.5$; organic matter $=$ $8.9 \mathrm{~g} \mathrm{~kg}^{-1} ; \mathrm{P}=5.4 \mathrm{mg} \mathrm{dm}{ }^{-3} ; \mathrm{Na}^{+}=0.23 \mathrm{cmol}_{\mathrm{c}} \mathrm{dm}^{-3}$; $\mathrm{K}^{+}=0.14 \mathrm{cmol}_{\mathrm{c}} \mathrm{dm}^{-3} ; \mathrm{Ca}^{2+}=4.05 \mathrm{cmol}_{\mathrm{c}} \mathrm{dm}^{-3}$; $\mathrm{Mg}^{2+}=3.9 \mathrm{cmol}_{\mathrm{c}} \mathrm{dm}^{-3} ; \mathrm{H}+\mathrm{Al}=2.0 \mathrm{cmol}_{\mathrm{c}} \mathrm{dm}^{-3} ; \mathrm{Al}^{3+}=$ $0.0 \mathrm{cmol}_{\mathrm{c}} \mathrm{dm}^{-3}$; sand $=912 \mathrm{~g} \mathrm{~kg}^{-1} ;$ silt $=13 \mathrm{~g} \mathrm{~kg}^{-1}$; and clay $=75 \mathrm{~g} \mathrm{~kg}^{-1}$.

The experiments were installed using a randomized block design, in a $7 \times 2$ factorial arrangement in the first experiment, with seven collection periods, two soil layers $(0-20 \mathrm{~cm}$ and $20-40 \mathrm{~cm}$ ) and four blocks. The second experiment corresponded to a $9 \times 2$ factorial arrangement, with nine collection periods, two soil layers $(0-20 \mathrm{~cm}$ and $20-40 \mathrm{~cm}$ ) and four blocks. In both experiments, each block (replicate) consisted of a $2.0 \times 27 \mathrm{~m}$ area, where nine experimental plots were allocated, each with $2.0 \times 3.0 \mathrm{~m}$, containing 20 plants (10 per row).

The preparation of the experimental areas was performed by harrowing. Subsequently, the planting rows were lifted and mulch was applied, followed by the transplantation of Goldex yellow melon seedlings grown in expanded polystyrene trays (Isopor ${ }^{\mathrm{TM}}$ ). Weed control was performed using the herbicide Gesaprim ${ }^{\mathrm{TM}}$, which has atrazine as an active ingredient. The control of pests and diseases was performed whenever necessary, using synthetic products already recommended for the melon variety used.

Irrigation management was performed based on the estimation of the maximum crop evapotranspiration (Allen et al. 2006). During transplantation, $300 \mathrm{~kg} \mathrm{ha}^{-1}$ of monoammonium phosphate were applied in both areas. Also in both areas, during the entire crop cycle, nutrients were supplied via fertigation, by a drip system, following a pre-established schedule for spreading fertilization, according to Deus et al. (2015) (Table 1), using the following sources: monoammonium phosphate $\left(48 \%\right.$ of $\mathrm{P}_{2} \mathrm{O}_{5}$ and $9 \%$ of $\mathrm{N}$ ), potassium nitrate ( $45 \%$ of $\mathrm{K}_{2} \mathrm{O}$ and $12 \%$ of $\mathrm{N})$, calcium nitrate $(15 \%$ of $\mathrm{N}$ and $19 \%$ of $\mathrm{Ca})$, phosphoric acid $\left(50 \%\right.$ of $\left.\mathrm{P}_{2} \mathrm{O}_{5}\right)$, potassium sulfate $\left(50 \%\right.$ of $\mathrm{K}_{2} \mathrm{O}$ and $17 \%$ of S), magnesium sulfate $(9 \%$ of $\mathrm{Mg}$ and $14 \%$ of S) and zinc sulfate (20\% of $\mathrm{Zn}$ and $18 \%$ of S). Along with the sources of N, P and K, $22 \mathrm{~kg}$ of Ca, $12 \mathrm{~kg}$ of Mg, $57 \mathrm{~kg}$ of S and $11 \mathrm{~kg}$ of Zn were applied per hectare, in the Haplic Vertisol. In the Typic Quartzipsamment, the applied doses of Ca, $\mathrm{Mg}$, $\mathrm{S}$ and Zn were, respectively, 54, 22, 54 and $9 \mathrm{~kg} \mathrm{ha}^{-1}$.

In the first experiment, soil samples were obtained in each useful plot at 7-day intervals, starting at 21 days and lasting until 63 days after transplantation (DAT). In the second experiment, soil samples were also collected at 7-day intervals, starting at 14 days and lasting until 70 DAT. After being air-dried, ground and passed through a 2.0$\mathrm{mm}$-mesh sieve, the soil samples were sent to the laboratory.

The fractions of exchangeable $\mathrm{K}$, nonexchangeable $\mathrm{K}$ and soluble $\mathrm{K}$ were determined in

Table 1 . Weekly nutrient doses $\left(\mathrm{kg} \mathrm{ha}^{-1}\right)$ applied via fertigation on the soils of the study areas.

\begin{tabular}{|c|c|c|c|c|c|c|}
\hline \multirow{2}{*}{ DAT } & \multicolumn{3}{|c|}{ - Haplic Vertisol - } & \multicolumn{3}{|c|}{ - Typic Quartzipsamment } \\
\hline & $\mathrm{N}$ & $\mathrm{P}$ & $\mathrm{K}$ & $\mathrm{N}$ & $\mathrm{P}$ & $\mathrm{K}$ \\
\hline 14 & - & - & - & 0.000 & 0.000 & 0.000 \\
\hline 21 & 17.156 & 17.156 & 9.581 & 5.664 & 6.730 & 3.767 \\
\hline 28 & 17.156 & 7.469 & 9.582 & 15.595 & 18.281 & 9.844 \\
\hline 35 & 17.156 & 7.469 & 13.200 & 15.535 & 18.281 & 10.120 \\
\hline 42 & 16.000 & 9.781 & 29.891 & 15.726 & 21.044 & 13.786 \\
\hline 49 & 24.891 & 8.125 & 29.893 & 21.753 & 22.148 & 27.397 \\
\hline 56 & 15.438 & 8.125 & 35.253 & 23.345 & 21.044 & 34.102 \\
\hline 63 & 11.625 & 4.484 & 44.394 & 16.193 & 11.652 & 36.613 \\
\hline 70 & - & - & - & 12.476 & 10.547 & 37.441 \\
\hline Total & 119.422 & 62.609 & 171.780 & 97.618 & 107.528 & 173.070 \\
\hline
\end{tabular}

DAT: days after transplanting. 
both experiments. Soluble K was extracted using distilled water and a calcium chloride solution $\left(\mathrm{CaCl}_{2}\right) 0.01 \mathrm{~mol} \mathrm{~L}^{-1}$ at a 1:10 soil:extractor ratio $(\mathrm{v} / \mathrm{v})$, followed by stirring for $5 \mathrm{~min}$. For the extraction of exchangeable $\mathrm{K}, 1 \mathrm{~mol} \mathrm{~L}^{-1}$ of ammonium acetate at $\mathrm{pH} 7.0$ was used at a 1:10 soil:extractor ratio $(\mathrm{v} / \mathrm{v})$, followed by stirring for 5 min (Helmke \& Sparks 1996). In turn, for the non-exchangeable $\mathrm{K}$, the soil samples initially received $1.0 \mathrm{~mol} \mathrm{~L}^{-1}$ of boiling $\mathrm{HNO}_{3}$ at a 1:10 ratio (v/v) (Helmke \& Sparks 1996). The concentration of non-exchangeable $\mathrm{K}$ was obtained by the difference between the $\mathrm{K}$ extracted with $1.0 \mathrm{~mol} \mathrm{~L}^{-1}$ of boiling $\mathrm{HNO}_{3}$ and the $\mathrm{K}$ extracted with $1.0 \mathrm{~mol} \mathrm{~L}^{-1}$ of ammonium acetate at $\mathrm{pH} 7.0$ (exchangeable K) (Helmke \& Sparks 1996). A new soil sample was used for each fraction of $\mathrm{K}$. Based on the $\mathrm{K}$ contents accumulated by the melon crop in this same experiment, in a Vertisol (Oliveira et al. 2016) and in a Typic Quartzipsamment (Oliveira 2017), the contents $\left(\mathrm{kg} \mathrm{ha}^{-1}\right)$ of exchangeable $\mathrm{K}$ that were lost or released in each period were estimated using the following expressions: $\Delta \mathrm{K}=$ observed $\mathrm{K}$ - estimated $\mathrm{K}$; and estimated $\mathrm{K}=$ initial $\mathrm{K}+\mathrm{K}$ fertilizer $-\mathrm{K}$ plant, where positive $\Delta \mathrm{K}$ values correspond to the $\mathrm{K}$ contents added to the exchangeable fraction, while negative $\Delta \mathrm{K}$ values correspond to the $\mathrm{K}$ contents removed from the exchangeable fraction. The initial and observed contents of $\mathrm{K}\left(\mathrm{kg} \mathrm{ha}^{-1}\right)$, in the $0-20 \mathrm{~cm}$ layer, were estimated according to Deus et al. (2015), considering the exchangeable $\mathrm{K}$ levels before installing the experiment and the values corresponding to each evaluation period, respectively.

Descriptive statistical analysis was performed for the non-cumulative $\mathrm{K}$ fractions obtained in each period, thus obtaining the means and the respective standard deviations. The comparison between soil layers was performed by the Tukey test at $5 \%$ of significance, using the Sisvar statistical software, version 5.6 (Ferreira 2011).

\section{RESULTS AND DISCUSSION}

The concentrations of water-soluble $\mathrm{K}$ in the Haplic Vertisol (Figure 2A) showed a tendency to increase from 21 DAT to 42 DAT, with a small decrease at 49 DAT; while, in the Typic Quartzipsamment (Figure 2B), there was a tendency to decrease this fraction during the crop development, with a peak at 42 DAT. In both soils, the highest water-soluble $\mathrm{K}$ levels were observed in the surface layer $(0-20 \mathrm{~cm})$.

The concentrations of $\mathrm{K}$ soluble in $\mathrm{CaCl}_{2}$ were also higher in the superficial layer, in both soils, although the behavior of this variable depends on the different depths and classes of soils considered in the different evaluation periods. In the Vertisol (Figure 2C), there was an increase in the $0-20 \mathrm{~cm}$ layer from 21 to 49 DAT, and a decrease in the $20-40 \mathrm{~cm}$ layer from 35 to 49 DAT. In the Quartzipsamment (Figure 2D), from 14 to 35 DAT, there was a tendency to decrease in the $0-20 \mathrm{~cm}$ layer; while, in the $20-40 \mathrm{~cm}$ layer, from 28 to 63 DAT, the values remained practically constant throughout the evaluation periods.

The increases in the contents of watersoluble $\mathrm{K}$ and $\mathrm{K}$ soluble in $\mathrm{CaCl}_{2}$ in the Vertisol are associated with increasing $\mathrm{K}$ applications throughout the melon cycle. In the Quartzipsamment, the resupply of $\mathrm{K}$ in the soil solution proved to be more dependent on fertigation, and the extraction of $\mathrm{K}$ by the melon crop led to a faster depletion of this nutrient in the soil solution. This probably occurred because Quartzipsamments, in general, are soils essentially composed of sand, naturally presenting a low cation exchange capacity and, consequently, limiting $\mathrm{K}$ retention in the solid phase (Mendes et al. 2016, Maniçoba et al. 2020). In the Quartzipsamment, the increase in soluble $\mathrm{K}$ in the 20-40 cm layer, at the end of the crop cycle, probably occurred due to leaching.

The concentrations of exchangeable $\mathrm{K}$ (Figures 2E and 2F), in both soils, were higher in the 0-20 cm layer. There was a downward trend from 21 to 42 DAT in both Vertisol layers (Figure 2E); while, in the Quartzipsamment (Figure 2F), the decrease occurred from 21 to 35 DAT, with a significant increase at 70 DAT. The levels of exchangeable K oscillated more intensely in the Quartzipsamment, possibly due to the low cation exchange capacity (Figure 2F). In this soil, $\mathrm{K}^{+}$shows a rapid movement, being susceptible to leaching losses (Carvalho et al. 2015, Ucker et al. 2016, Taiwo et al. 2018). Due to the low K buffering capacity of the Quartzipsamment, the prolonged cultivation with species that present high $\mathrm{K}$ extraction, such as melon (Oliveira et al. 2016), can lead to a more accelerated $\mathrm{K}$ depletion in this soil, when compared to the Vertisol. The increase of exchangeable $\mathrm{K}$ in both soil layers, at the end of the crop cycle, was also due to the stabilization of $\mathrm{K}$ 

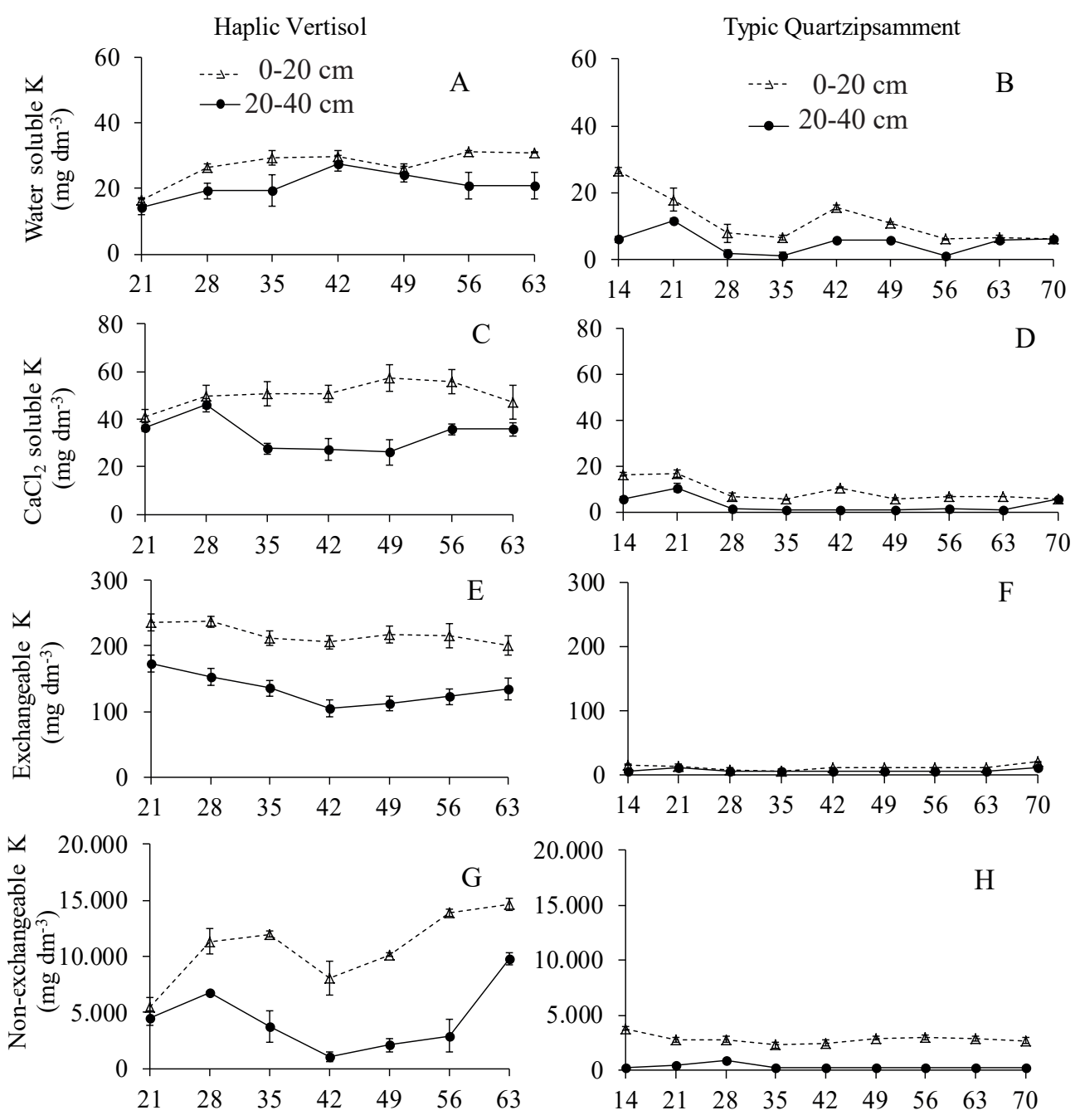

Days after transplanting the seedlings

Figure 2. Concentrations of soluble, exchangeable and non-exchangeable potassium in the Haplic Vertisol (A, C, E, G) and in the Typic Quartzipsamment (B, D, F, H), as a function of the evaluation periods and soil depths.

absorption by the plant, combined with the increase in the total amount of $\mathrm{K}$ applied via fertigation.

In both soils, the concentrations of nonexchangeable $\mathrm{K}$ were also higher in the $0-20 \mathrm{~cm}$ layer, showing a greater difference between the soil layers, when compared to the remaining $\mathrm{K}$ fractions. In the Vertisol (Figure 2G), the oscillation of this $\mathrm{K}$ fraction was similar between layers; that is, there was an increase at $28 \mathrm{DAT}$, followed by a decrease at 42 DAT, and again an increase from 49 DAT. In the Quartzipsamment (Figure 2H), the curves obtained for the studied soil layers showed a quite different behavior; that is, there was a decrease until 35 DAT in the $0-20 \mathrm{~cm}$ layer, and then a slight increase from this period until 56 DAT, while, in the $20-40 \mathrm{~cm}$ layer, there was an increase in the contents of nonexchangeable K until 28 DAT, followed by a decrease until 56 DAT.

The initial decrease of non-exchangeable $\mathrm{K}$ in the Quartzipsamment, in the 0-20 cm layer, was consistent with the increase in the contents of soluble and exchangeable $\mathrm{K}$. It has probably occurred due to the displacement of non-exchangeable $\mathrm{K}$ by calcium, since it was present in high concentrations in the soil, favoring the release of $\mathrm{K}$ to the soil solution (Santos et al. 2013, Steiner \& Lana 2018, Portela et al. 2019). Although of small magnitude, the increase in the non-exchangeable levels of $\mathrm{K}$ up to $28 \mathrm{DAT}$, in the 20-40 cm layer, may indicate a possible $\mathrm{K}$ leaching from the soil-surface solution and its subsequent 
fixation. The mineralogy of Vertisols indicates the presence of 2:1 and mica minerals in the clay fraction, which may favor the fixation of the leached $\mathrm{K}$ into lower layers (Santos et al. 2013, Chatterjee et al. 2014, Portela et al. 2019).

Considering the averages of periods and soil layers, the contents of non-exchangeable $\mathrm{K}$ were higher than the contents of the remaining fractions, especially in the Vertisol (Table 2). The fraction of $\mathrm{K}$ soluble in $\mathrm{CaCl}_{2}$ was higher than the fraction soluble in water in the Vertisol, but similar in the Quartzipsamment. The concentration of nonexchangeable $\mathrm{K}$, on average, was five times higher in the Vertisol; while, for the exchangeable K, the Vertisol was 18 times superior to the Neosol. The highest levels of all forms of $\mathrm{K}$ in the Vertisol are related to the mineralogy of the clay fraction of these soils, usually constituted by 2:1 type minerals of the K-rich sand and clay fractions, such as micas, orthoclase and biotite, which are more susceptible to weathering, controlling the dynamic balance between the forms of soluble, exchangeable and nonexchangeable potassium in these soils, constituting important $\mathrm{K}$ reserves for plants in the long run (NajafiGhiry et al. 2019, Portela et al. 2019, Maniçoba et al. 2020). Furthermore, minerals from the clay fraction, such as illite and montmorillonite, which are persistent in Vertisols and practically nonexistent in Quartzipsamments (Carvalho et al. 2015), present a high K-retention capacity due to their high surface load and specific surface, as aforementioned.

Regardless of the evaluation periods, the contents of all fractions of $\mathrm{K}$, in both soils, were higher in the $20-40 \mathrm{~cm}$ layer (Table 2). The contents of $\mathrm{K}$-water, $\mathrm{K}-\mathrm{CaCl}_{2}$, exchangeable $\mathrm{K}$ and nonexchangeable $\mathrm{K}$ were, respectively, approximately $29,50,63$ and $144 \%$ higher in the $20-40 \mathrm{~cm}$ layer of the Vertisol, and 131, 176, 67 and $791 \%$ in the same layer of the Quartzipsamment. Therefore, for both soils, the non-exchangeable $\mathrm{K}$ fraction obtained the greatest difference between the soil layers.

The highest levels of soluble and exchangeable $\mathrm{K}$ verified in the $0-20 \mathrm{~cm}$ layer of the Vertisol were expected due to the fertilization which occurred in this layer, and also due to the low leaching susceptibility of this soil, given its high cation exchange capacity and mineralogy (Ucker et al. 2016). Although a greater similarity between the soil layers was expected for the contents of soluble and exchangeable $\mathrm{K}$, due to a possible leaching, this did not occur in the Quartzipsamment. In this sense, the $\mathrm{K}$ leaching in the Quartzipsamment occurred only in periods of greater release of this nutrient, combined with low absorption rates by plants.

Throughout the melon cycle in the Vertisol, $\mathrm{K}$ was added to the exchangeable fraction at 21 and 28 DAT (Table 3); while, in the other periods, this fraction was 'drained', especially at 56 DAT. There was an alternation between additions and losses of exchangeable $\mathrm{K}$ in the Quartzipsamment; but, in the Vertisol, the greatest losses occurred at the end of the crop cycle (63 and 70 DAT). These results are consistent with the increase in the contents of the nonexchangeable fraction from 49 to 63 DAT, in both soils (Figures $2 \mathrm{G}$ and $2 \mathrm{H}$ ), indicating that there was a greater $\mathrm{K}$ fixation in this period, as well as a lower amount of $\mathrm{K}$ accumulated by plants. Thus, greater $\mathrm{K}$ losses in the Quartzipsamment occur due to the lower absorption of $\mathrm{K}$ by the melon crop, leading to a possible increase in the $\mathrm{K}$ fixation, and especially leaching. In the total balance ( $\Delta \mathrm{K}$ total), there was a $\mathrm{K}$ loss of $23.46 \mathrm{~kg} \mathrm{ha}^{-1}$ in the Vertisol and $49.65 \mathrm{~kg} \mathrm{ha}^{-1}$ in the Quartzipsamment, being equivalent to 13.7 and $28.7 \%$, respectively. Therefore, in both soils, it is necessary to adjust the $\mathrm{K}$ doses to be applied in each period, in order to improve the synchrony between

Table 2. Content of soluble (K-water and $\left.\mathrm{K}-\mathrm{CaCl}_{2}\right)$, exchangeable and non-exchangeable potassium in the sampled soil layers.

\begin{tabular}{|c|c|c|c|c|}
\hline Layers & Water soluble K & $\mathrm{CaCl}_{2}$ soluble $\mathrm{K}$ & Exchangeable K & Non-exchangeable K \\
\hline & \multicolumn{4}{|c|}{ Haplic Vertisol } \\
\hline $0-20 \mathrm{~cm}$ & $27.313 \mathrm{a}^{*}$ & $50.362 \mathrm{a}$ & $217.638 \mathrm{a}$ & $10,795.317 \mathrm{a}$ \\
\hline $20-40 \mathrm{~cm}$ & $21.054 \mathrm{~b}$ & $33.617 \mathrm{~b}$ & $133.670 \mathrm{~b}$ & $4,412.290 \mathrm{~b}$ \\
\hline \multirow[t]{2}{*}{ Mean } & 24.184 & 41.989 & 175.654 & $7,603.803$ \\
\hline & \multicolumn{4}{|c|}{ Typic Quartzipsamment } \\
\hline $0-20 \mathrm{~cm}$ & $11.544 \mathrm{a}$ & $9.048 \mathrm{a}$ & $12.122 \mathrm{a}$ & $2,824.613 \mathrm{a}$ \\
\hline $20-40 \mathrm{~cm}$ & $4.984 \mathrm{~b}$ & $3.272 \mathrm{~b}$ & $7.233 \mathrm{~b}$ & $317.118 \mathrm{~b}$ \\
\hline Mean & 8.264 & 6.160 & 9.677 & $1,570.865$ \\
\hline
\end{tabular}


Table 3. Contents $\left(\mathrm{kg} \mathrm{ha}^{-1}\right)$ of $\mathrm{K}$ applied via fertilizer ( $\mathrm{K}$ fert), accumulated by the plant (K plant) and available in the soil (K soil), and variation in the amount of exchangeable $\mathrm{K}(\Delta \mathrm{K})$, in each period.

\begin{tabular}{|c|c|c|c|c|c|c|c|c|}
\hline \multirow{2}{*}{ DAT } & \multicolumn{4}{|c|}{ Haplic Vertisol - } & \multicolumn{4}{|c|}{ - Typic Quartzipsamment } \\
\hline & $\mathrm{K}$ fert & K plant 1 & K soil* & $\Delta \mathrm{K}$ & $\mathrm{K}$ fert & $\mathrm{K}$ plant 2 & K-soil* & $\Delta \mathrm{K}$ \\
\hline 14 & - & - & - & - & 0.00 & 3.76 & 22.72 & 3.76 \\
\hline 21 & 9.58 & 37.94 & 329.95 & 37.94 & 3.77 & 7.23 & 28.18 & 8.92 \\
\hline 28 & 9.58 & 40.86 & 332.02 & 42.93 & 9.84 & 15.85 & 11.54 & -5.17 \\
\hline 35 & 13.20 & 44.68 & 296.41 & 7.51 & 10.12 & 27.99 & 8.42 & 3.57 \\
\hline 42 & 29.89 & 44.39 & 288.09 & -17.79 & 13.79 & 38.83 & 15.18 & 17.51 \\
\hline 49 & 29.89 & 39.98 & 303.69 & -6.60 & 27.40 & 40.13 & 15.44 & 5.45 \\
\hline 56 & 35.25 & 31.45 & 301.32 & -22.85 & 34.10 & 26.02 & 15.18 & -15.62 \\
\hline 63 & 44.39 & 18.81 & 281.34 & -64.61 & 36.61 & 0.00 & 15.44 & -43.89 \\
\hline 70 & - & - & - & - & 37.44 & 0.00 & 35.97 & -24.18 \\
\hline Total & 171.78 & 258.10 & - & -23.47 & 173.07 & 159.81 & - & -49.65 \\
\hline
\end{tabular}

DAT: days after transplantation; $\mathrm{K}$ plant 1 and $\mathrm{K}$ plant 2: estimated using the regression models adjusted by Oliveira et al. (2016) and Oliveira (2017), respectively;

* estimated according to Deus et al. (2015).

the application and absorption rates by the plant, thus increasing the efficiency of potassium fertilization in the melon crop.

\section{CONCLUSIONS}

1. The non-exchangeable $\mathrm{K}$ fraction was dominant in both soils, especially in the $0-20 \mathrm{~cm}$ layer, representing an important reserve of this nutrient for melon cultivation, especially in Haplic Vertisols;

2. The decrease in the concentrations of the soluble and exchangeable forms and the increase in the non-exchangeable form of potassium indicated an increase of this nutrient by fixation in the Vertisol and by leaching in the Typic Quartzipsamment, at the end of the melon cycle, when there was less K accumulated by the plant;

3. In areas with Vertisol and Typic Quartzipsamment, an increased synchrony between the application and accumulation rates of $\mathrm{K}$ in the melon crop can increase the efficiency of potassium fertilization.

\section{REFERENCES}

ALLEN, R. G.; PEREIRA, L. S.; RAES, D.; SMITH, M. Evapotranspiración del cultivo: guias para la determinación de los requerimientos de agua de los cultivos. Roma: FAO, 2006. (Estudio riego e drenaje paper, 56).

CARVALHO, R. P.; DANIEL, O.; DAVIDE, A. C.; SOUZA, F. R. Atributos físicos e químicos de um Neossolo Quartzarênico sob diferentes sistemas de uso e manejo. Revista Caatinga, v. 28, n. 1, p. 148-159, 2015.
CHATTERJEE, D.; DATA, S. C.; MANJAIAH, K. M. Fractions, uptake and fixation capacity of phosphorus and potassium in three contrasting soil orders. Journal of Soil Science and Plant Nutrition, v. 14, n. 3, p. 640-656, 2014.

DEUS, J. A. L.; SOARES, I.; NEVES, J. C.; MEDEIROS, J. F.; MIRANDA, F. R. Fertilizer recommendation system for melon based on nutritional balance. Revista Brasileira de Ciência do Solo, v. 39, n. 2, p. 498-511, 2015.

EMPRESA BRASILEIRA DE PESQUISA AGROPECUÁRIA (Embrapa). Centro Nacional de Pesquisa de Solos. Manual de métodos de análise de solo. 2. ed. rev. atual. Rio de Janeiro: Embrapa, 2011.

EMPRESA BRASILEIRA DE PESQUISA AGROPECUÁRIA (Embrapa). Sistema brasileiro de classificação de solos. Brasília, DF: Embrapa, 2006.

FERREIRA, D. F. Sisvar: a computer statistical analysis system. Ciência e Agrotecnologia, v. 35, n. 6, p. 10391042, 2011.

FIGUEIRÊDO, M. C. B.; GONDIM, R. S.; ARAGÃO, F. A. S. (ed.). Produção de melão e mudanças climáticas: sistemas conservacionistas de cultivo para redução das pegadas de carbono e hídrica. Brasília, DF: Embrapa, 2017.

FILGUEIRA, F. A. R. (ed.). Novo manual de olericultura: agrotecnologia moderna na produção e comercialização de hortaliças. Viçosa: UFV, 2013.

GURAV, P. P.; DATTAB, S. C.; RAYC, S. K.; CHOUDHARID, P. L.; AHMED, N. Assessment of potassium release threshold levels of Vertisols (shrinkswell soils) in different agro-ecological regions of India. Applied Clay Science, v. 165, n. 1, p. 155-163, 2018.

HELMKE, P. A.; SPARKS, D. L. Lithium, sodium, rubidium and cesium. In: SPARKS, D. L.; PAGE, A. L.; 
HELMKE, P. A.; LOEPPERT, R. H.; SOLTANPOUR, P. N.; TABATABAI, M. A.; JOHNSTON, C. T.; SUMNER, M. E. Methods of soil analysis: part 3: chemical methods. Madison: SSSA/ASA, 1996. p. 551-574. (Book series, 5).

INSTITUTO BRASILEIRO DE GEOGRAFIA E ESTATÍSTICA (IBGE). Produção agrícola municipal: melão: área plantada, área colhida, quantidade produzida, rendimento médio e valor da produção. 2019. Disponível em: https://sidra.ibge.gov.br/tabela/1612. Acesso em: 02 jul. 2020.

KASEKER, J. F. Forms of potassium in southern Brazilian soils and effect of liming on $K$ uptake by pine seedlings. 2016. Thesis (Doctorate in Soil Science) - Universidade Estadual de Santa Catarina, Lages, 2016.

LESTER, G. E.; JIFON, J. L.; MAKUS, D. J. Impact of potassium nutrition on postharvest fruit quality: melon (Cucumis melo L.): case study. Plant and Soil, v. 335, n. 1, p. 117-331, 2010.

MANIÇOBA, F. E.; GONÇALO FILHO, F.; RÊGO, L. G. S.; SOUZA, C. M. M.; SILVA, A. C. R.; LIMA, R. N. S.; FERREIRA NETO, M.; MIRANDA, N. O. Pedon characterization in the Caatinga biome area in Chapada Apodi, RN, Brazil. Journal of Agricultural Science, v. 12, n. 9, p. 138-148, 2020.

MENDES, W.; ALVES JUNIOR, J.; CUNHA, P. C. R.; SILVA, A. R.; EVANGELISTA, A. W. P.; CASAROLI, D. Potassium leaching in different soils as a function of irrigation depths. Revista Brasileira de Engenharia Agrícola e Ambiental, v. 20, n. 11, p. 972-977, 2016.

MOUHAMAD, R.; ALSAEDE, A.; IQBAL, M. Behavior of potassium in soil: a mini review. Chemistry International, v. 2, n. 1, p. 58-69, 2016.

NAJAFI-GHIRY, M.; REZABIGI, S.; HOSSEINI, S.; BOOSTANI, H. R.; OWLIAIE, H. R. Potassium fixation of some calcareous soils after short term extraction with different solutions. Archives of Agronomy and Soil Science, v. 65, n. 7 , p. 897-910, 2019.

OLIVEIRA, F. S.; OLIVEIRA, F. S.; ARAUJO, J. L.; ROCHA, R. C. C.; ROCHA, H. G. C. Partição e acumulação de nutrientes no meloeiro amarelo fertirrigado em condições semiáridas. Irriga, v. 21, n. 3, p. 545-560, 2016.
OLIVEIRA, S. R. Marcha de absorção e balanço de nutrientes no sistema solo-planta para o meloeiro fertirrigado. 2017. Dissertação (Mestrado em Horticultura Tropical) - Universidade Federal de Campina Grande, Campina Grande, 2017.

PONTES, R. S. S.; PONTES, A. S. C.; ARAGÃO, C. A.; PONTES, S. S. Cultivo do melão fertirrigado com potássio calibrado com medidores de íons específicos. Horticultura Brasileira, v. 28, n. 2, p. 155-165, 2010.

PORTELA, E.; MONTEIRO, F.; FONSECA, M.; ABREU, M. M. Effect of soil mineralogy on potassium fixation in soils developed on different parent material. Geoderma, v. 343, n. 1, p. 226-234, 2019.

SANTOS, H. C.; OLIVEIRA, F. H. T.; HOFFMAN, R. B.; SANTOS, D. Relações quantidade/intensidade de potássio em solos representativos do estado da Paraíba - Brasil. Amazonian Journal of Agricultural and Environmental Sciences, v. 56, n. 4, p. 338-346, 2013.

SILVA, M. C.; SILVA, T. J. A.; BONFIM-SILVA, E. M.; LORRAINE, N. F. Características produtivas e qualitativas de melão rendilhado adubado com nitrogênio e potássio. Revista Brasileira de Engenharia Agrícola e Ambiental, v. 18, n. 6, p. 581-587, 2014.

STEINER, F.; LANA, M. C. Contribution of nonexchangeable $\mathrm{K}$ in soils from southern Brazil under potassium fertilization and successive cropping. Revista Ciência Agronômica, v. 49, n. 4, p. 547-557, 2018.

SUN, M.; ZHANG, D.; WANG, Z. How to predict the sugariness and hardness of melons: a near-infrared hyperspectral imaging method. Food Chemistry, v. 218, n. 1, p. 413-421, 2017.

TAIWO, A. A.; ADETUNJI, M. T.; AZEEZ, J. O.; ELEMOM, K. O. Kinetics of potassium release and fxation in some soils of Ogun state, Southwestern, Nigeria as infuenced by organic manure. International Journal of Recycling of Organic Waste in Agriculture, v. 7, n. 3, p. 251-259, 2018.

UCKER, F. E.; CAMPOS, A. B. de; HERNANI, L. C.; MACÊDO, J. R.; MELO, A. S. Movimentação vertical do íon potássio em Neossolos Quartzarênicos sob cultivo com cana-de-açúcar. Pesquisa Agropecuária Brasileira, v. 51, n. 9, p. 1548-1556, 2016. 